\title{
Improvement of Physical, Honesty, Discipline and Cooperation in Class IV Elementary School Students through Circuit Training Learning Model
}

\author{
Dean Novianti ${ }^{1}$, I Made Sriundy Mahardika ${ }^{2}$, Abdul Rachman Tuasikal ${ }^{2}$ \\ ${ }^{1}$ Master Student in Sport Education, Universitas Negeri Surabaya, Indonesia \\ ${ }^{2}$ Lecturer in Sport Education, Universitas Negeri Surabaya, Indonesia \\ Deannovianti1978@gmail.com
}

\begin{abstract}
Physical education program for sport and health allocates four lesson hour of which each hour consists of 35 minutes in one week. It requires an innovative and efficient learning model in order to improve physical fitness, honesty, discipline, and cooperation. The researcher developes a circuit training learning model in the from circuit games which is a modified form of circuit training. The study aim to examine the effectiveness of the circuit training learning model in improving physical fitness, honesty, discipline, and cooperation in students of Elementary School Sidoarjo. The type of research used is quantitative and qualitative by using research and development method, and data analysis using ANOVA. The data collection process is carried out by pre-test and post-test and then the results of the research data are analyzed using SPSS series 2.0. The results of the study shows (1) the sig value of 0,011 smaller than the 0,05 ( $p<0,05)$, meaning that there is the difference in the results of the TKJ I test on groups of students who are not treated compared to the group of students who are given the learning model. (2) the average group of students who are not given the treatment (control group) is 12,50 while for the group of studentsgiven treatment (experimental group) is 15,15, meaning that there is an increase in test results againts the experimental group at $45 \%$, (4) there is an increase in the observations of the discipline attitude from the control group compared to the experimental group at $35 \%$, (5) there is an increase in the observations of the discipline attitudes of the control group compared to the experimental group at 55\%. Based on the above analysis it can be cocluded that the circuit training learning model can improve physical fitness and cultivate honesty, discipline and cooperattion in students of Elementary School.
\end{abstract}

Keywords

model; physical; honesty, discipline; cooperation; circuit training

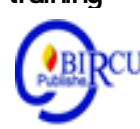

\section{Introduction}

Physical education, sport and health are one of the main subjects that must be taught in schools, ranging from elementary school through high school. This was stated in the Act (Act) No. 20 of 2003 on National Education System (Education) of Chapter X of Article 37, which contains primary and secondary education curriculum. Physical education needs to be improved in the school environment, with physical education is expected to increase student physical fitness, in addition to the academic field will also increase.

Physical education is different from the sport, because of the physical education teaching physical activity that aims to maintain a healthy body, strengthen muscles, and shape the character of the students, while in sport there are physical activities that require high-level 
skills and in actual use rules that have been agreed upon. Implementation of learning sports physical education and health in primary schools there are not in accordance with the concept of learning sports physical education and health.

Many teachers physical education in primary school that focuses on the assessment of achievements by students, teachers assume and judge well when students excel in sports that are taught, besides there are also teachers physical education judging from the results achieved by students not quantify processes that have been performed by students. Physical education teachers should clearly lead students to not solely the pursuit of victory, but the physical education teachers should be able to show that the struggle to achieve a victory that must be respected.

In addition to the physical education teacher also still exist that use their learning according to what the actual rules of the game and, in fact physical education teacher at the school had to adjust the game to the circumstances and conditions in the school. Allocation of time in physical education lessons exercise and health is still less contribute in improving the physical fitness of students, it is necessary to be a development model of learning that can contribute optimally to achieve the goals of education.

A physical education teacher is required to create a conducive learning atmosphere and fun in the learning process of physical education and sport so as to encourage Shiva's health can develop all their creativity with the help of a teacher. For that a teacher physical education should prepare materials/models of learning interesting and varied that can make learning more active, innovative, creative and fun, and foster interest and motivation of students in the following study physical education sport and health, in addition to the learning model will facilitate teachers to transfer the experience and knowledge to the students.

The process is the most important thing in learning because the process is what determines the learning objectives, which will be achieved or not achieved. The achievement of the learning process is characterized by a change in behavior. The learning process of physical exercise and health education requires the development of model of learning by reference to the characteristics of the learning model that has the purpose to serve as a guide and can be applied to most of the educational units.

\section{Review of Literature}

Sports and Health Physical Education is one of the education carried out in Indonesia which has a learning system based on theory and practice. Sports and Health Physical Education is generally taught to students in elementary schools. Sports and Health Physical Education is a learning process through physical activities where each student is obliged to do physical activities to improve his physical fitness. Sports and Health Physical Education not only focuses on improving physical fitness or physical development, but also developing cognitive and affective aspects.

In the Minister of Education and Culture Regulation (Permendikbud) No. 64 of 2013 mentioned that.Sports and Health Physical Education is an integral part of overall education, aims to develop aspects of physical fitness, movement skills, critical thinking skills, social skills, reasoning, emotional stability, moral actions, aspects of healthy lifestyle and the introduction of a clean environment through sports physical activities and selected health systematically planned in order to achieve the goals of National Education.

According to Widijoto (2006) in Angga (2017) physical education is as follows. Sports and health physical education is a psychomotor activity carried out on the basis of knowledge 
(cognitive) and at the time of doing there will be personal behavior related to attitudes or affective (such as cooperation, helping each other), or physical education, sports and health can be interpreted as a process learning through physical activities that are designed systematically to improve physical fitness, develop motor skills, which will be good implementation if supported by knowledge of how to do it, healthy living behaviors, active, will develop an attitude of honesty, discipline, self-confidence, tough, emotional control, and cooperation and mutual assistance.

According to Elena (2014) said that. Physical education lessons imprint, throughout the time, a life discipline for students, and a manner of discharge from everyday life, that will have positive repercussions for individuals actively involved in the didactic process, represented by physical education lessons, starting with school education and ending with higher education.

According to the expert, the researcher can conclude that Sports Physical and Health education lessons are printed all the time, can discipline students' attitudes and behaviors and indifferent attitudes towards daily life. This will have a positive impact on each individual who is actively involved in the didactic process. Physical education lessons start from school education including elementary school students and end with the highest education.

Based on some of these opinions it can be concluded that Physical Education Sports and Health is one part of education by carrying out planned motion activities and aims to improve physical fitness and can foster affective abilities, namely forming a person who has a soul and noble character including honesty, discipline and good cooperation.

\section{Research Method}

Based on the purpose of the research to be conducted, the research method used in this study Gal \& Borg (2003) argue that. Development research is a study that is designed to produce new products and procedures, which are carried out systematically in field testing, evaluation and filtering to find specific criteria, quality or close to the standard. is to use the Research and Development method.

The steps in the learning model innovation that will be developed by researchers through the following stages:

\section{Step Activities}

1. Pre-Development - Literature Study - Need analysis

- Develop research proposals

2. Planning and making the initial product (Learning model innovation) Development of the first

3. Product revisions Product validation from PJ OK learning experts and practitioners

4. Test the initial product using small groups

5. Second product revision

6. Second try using large groups 7 Revision of the final product

Dissemination of the results of the final product learning model innovation in the form of a Learning Implementation Plan (RPP)

Furthermore, this development research will be followed up with action research, according to Cresswell (2012) stating that. Action research has an applied focus. Similar to mixed research methods, action research uses data collection based on either quantitative or qualitative methods or both. Thus action research designs are systematically carried out by researchers to gather information about, and subsequently improve. The design of this study 
uses qualitative and quantitative approaches (blending qualitative and quantitative research methods) (Murray, 2003).

\section{Quantitative Approach}

The design of this study used a pretest-posttest control group design. In this design the research subjects were drawn from the population randomly, the design consisted of two groups, where the group that was treated was the group called the experimental group while the group without treatment was the control group. (Sriundy, 2015)

a. Experiment Group

Pre Test

- TKJ I (Indonesian Physical Fitness Test)

- Questionnaire Honesty, discipline, cooperation

Treatment

Circuit training learning model to improve physical fitness, honesty, discipline and cooperation POST TEST

- TKJ I (Indonesian Physical Fitness Test)

- Questionnaire Honesty, discipline, cooperation

b. Control group

Pre Test

- TKJ I (Indonesian Physical Fitness Test)

- Questionnaire Honesty, discipline, cooperation

Without Treatment

- Conventional Learning POST TEST

- TKJ I (Indonesian Physical Fitness Test)

- Questionnaire Honesty, discipline, cooperation

\section{Qualitative Approaches}

This qualitative research uses several tools to collect data. Data collection techniques in qualitative research include: observation, interviews, documentation and triangulation /combination. (Sugiyono, 2010).

\section{Discussion}

From the results of the calculation of the validation evaluation sheet of observations of honesty, discipline and cooperation by experts in tables 4.7, 4.8 and 4.9 the average score on the item is $(-0.67,-0.33$ and 0$)$, the average value is located between values 1 and -1 and are stated in the relevant criteria. This shows that an honest, disciplined and collaborative attitude observation sheet is relevant to be tested and used in physical education and sports learning for grade IV elementary school students, but there are still some revisions / suggestions given by experts related to an honest attitude observation sheet, discipline and cooperation that will be tested are as follows:

1. There is no time allocation

2. Observation sheet is appropriate to use but there are sentences that are not synchronized

3. There are still some questions that are not quite right

\subsection{Physical Fitness}

The results of the physical fitness pretest and posttest class IV students without using the circuit training (control group) learning model are the results of raw data which are then 
adjusted to the assessment of the Indonesian Physical Fitness Test norms (TKJ I). (SriUndy, 2009).

1. Data Normality Test

Based on the results of the calculation of the data shows that the significance value of pre-test and post-test without the treatment model of learning is $1.00>0.05$ (receive HO), which means that all data on the TKJ I test in the group without the treatment model of learning is normally distributed.

2. Data Reliability Test

Based on the calculation of the pre test results of the group of students without the treatment of the learning model is $0.721>0.7$, which means that the data is reliable or reliable and the calculation of the results of the post test results of the group of students without the treatment of the learning model is $0.770>0.7$ which means that the data reliable / reliable

Based on the results of the pretest and posttest physical fitness grades IV students with the treatment of the circuit training learning model then the calculation and processing for the significance test which is a hypothesis test using SPSS are:

1. Data Normality Test

Based on the results of normality test data calculation shows that the significance value of pre-test with the learning model treatment is 0.834> 0.05 (accept HO), and the significance value of the test post with the learning model treatment is $0.484>0.05$ (receive $\mathrm{HO}$ ), which means that all data on TKJ I tests on groups of students using the learning model are normally distributed.

2. Data Reliabiliaty Test

Based on the calculation of the reliability test data, the pre-test group of students with the treatment of learning models is $0.788>0.7$, which means that the data is reliable or reliable and the calculation of the results of the Based on testing the data above which shows that the results of pre-test data and TKJ I test post against groups of students with treatment and without treatment with learning models the results are normally distributed and reliable.

For further homogeneity tests and different tests using Paired Samples Statistics, are as follows: test post results from the group of students without treatment of the learning model is $0.758>0.7$ which means that the data is reliable / reliable.

1. Homogeneity Test

Based on homogeneity test data calculations for pre-test data and TKJ I test post groups of students who were given treatment and without treatment learning models the significance value was $0.060>0.05$. This means that the variance of TKJ I data with the treatment and without treatment learning models has the same value. (Homogeneous)

2. Difference Test

Based on the results of the calculation of the average difference test on the results of the pre-test and post-test data on groups of students who were given treatment and without treatment with learning models had a significance value of 0.011 ie $<0.05$ (starting Ho). This means that there is a difference between TKJ I test results for groups of students who were not given treatment compared to groups of students who were given treatment models of learning. The average group of students who were not given treatment (the control group) was 12.50 while for the group of students who were given treatment (the experimental group) $=15.15$. This means that there is an increase in test results on the experimental group with the treatment of the Circuit Training learning model. 


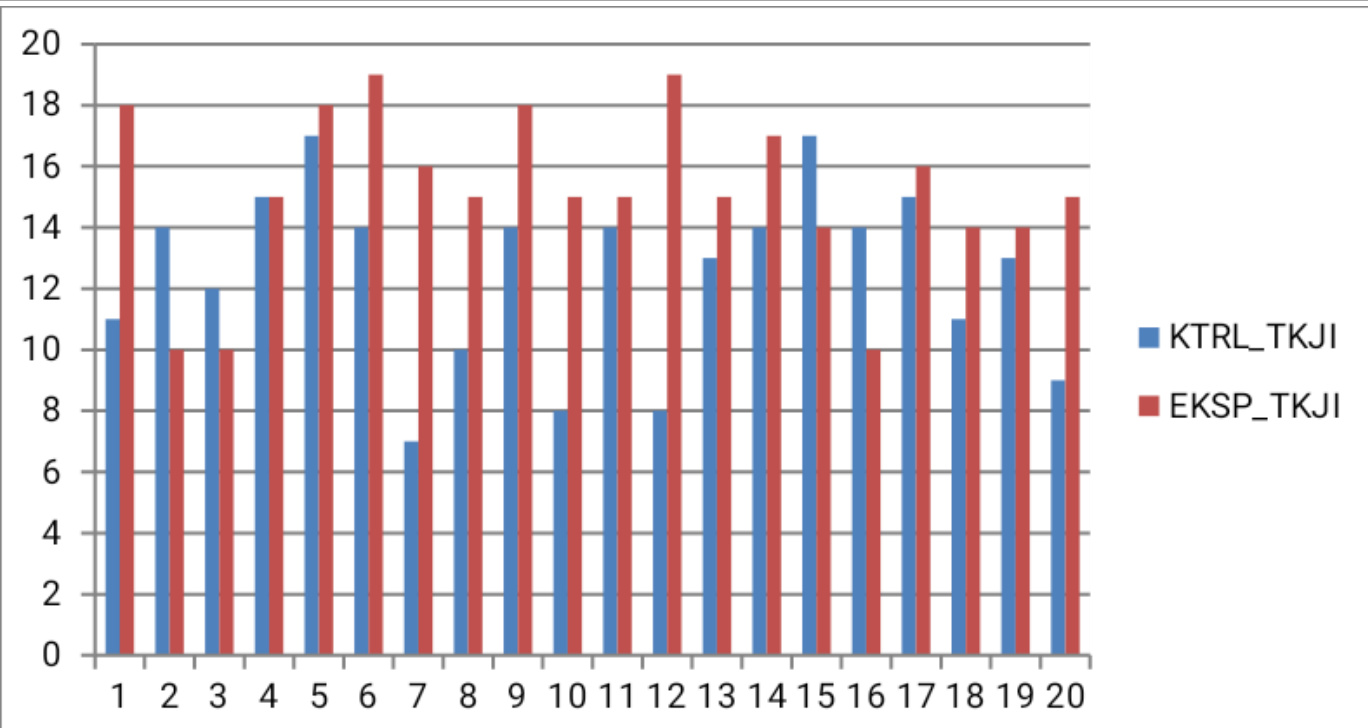

Figure 1. Comparison of Pre-Test and Post-Test Results in Control Group Students and Experiment Group Students

\subsection{Honesty, Discipline and Cooperation}

1. Honesty

Based on observations made by class teachers and PJ OK teachers that the control group that was not given the treatment of learning models in the field showed the following results: Honest attitude of students with very good criteria $=2$ people, good $=15$ people, Enough $=3$ people.

\section{Discipline}

Based on observations made by class teachers and PJ OK teachers that groups of students who were not treated with learning models in the field showed the following results: Discipline attitude of students with very good criteria $=2$ people, good $=15$ people, enough $=2$ people

\section{Cooperation}

Based on observations made by class teachers and PJ OK teachers that groups of students who were not given the treatment of learning models in the field showed the following results: The attitude of student cooperation with good criteria $=18$ people, enough $=2$ people

The results of observations of aspects of honesty, discipline and collaboration carried out with pre-test and post test to students of the control group and the experimental group showed the results with an average index that is in the honesty aspect without the treatment model of circuit training learning the average results with enough categories $=3$ people, good $=15$ people, very good $=2$ people compared with the treatment model of learning the average results of the good category $=11$ and very good $=9$ people ie there is an increase with the treatment model of learning in the original category very good from 2 people (10\%) to 9 people $(45 \%)$. The results of the average aspects of the discipline without the treatment of sufficient learning categories category $=2$ people, good $=16$ people and very good $=2$ people compared to the results of the treatment categories of learning models good $=13$ people and very good $=$ 7 people, an increase in results with the treatment is very good category $=2$ people $(10 \%)$ to 7 people $(35 \%)$. While the results of the cooperation aspect without sufficient treatment category $=2$ people and good $=18$ people, while with good category treatment $=9$ people and very good 11 people, an increase in the category of very good from 0 people $(0 \%)$ to 11 people $(55 \%)$. 


\section{Conclusion}

Based on the results of research and discussion of the circuit training learning model that can improve physical fitness and instill honesty, discipline and cooperation, it can be summarized the following research:

1. Circuit training model of learning is structured that aims to improve physical fitness and instill honesty, discipline and cooperation that can be applied in Buduran Public Elementary School, especially for fourth grade students.

2. The circuit training learning model has the effectiveness to improve physical fitness and instill honesty, discipline and cooperation towards fourth grade students at SD Negeri Buduran Sidoarjo

3. There are differences in the results of the pre-test and post-test of the group of students who were given the treatment of the circuit training learning model compared to the group of students who were not given the treatment.

\section{References}

Angga, 2006. The formation of elementary school student characters through traditional games in physical education in sports and health

Andika, 2017. Study of Honest Character Development in Early Childhood

Bompa, T.O, 1994. Theory and Methodology of Training, 3rd edition, Toronto, Ontorio: Kendall / Hunt Publishing Company

Bitar. (2019, J anuary). Definition, Benefits, and Form of Collaboration with Complete

Examples. Downloaded from (https://www.gurupendukasi.com/2019/02/peng understanding-benefits-and-shape-of-business-exploise-example.html)

Creswell, W, J ohn, 2016. Research Design: Qualitative, Quantitative and Mixed Approaches, Yogyakarta: Student Library

Cerika, 2011. Optimizing the Formation of Character and Discipline of Primary School Students Through Physical Education in Sport and Health. Yogyakarta

Djoko, 2002. Basic training. Yogyakarta: Lukman offset

Desmita. 2011. Psychology of Student Development. Bandung: PT Remaja Rosdakarya

Elena Lupu, 2014. The Importance of Physical Education Lessons For The Formation Of Self-

Control And The Decrease Of The Reaction To Frustration Of Students. Romania

Giri Wiarto, 2015. Learning Innovations in Physical Education. Yogyakarta: Laksitas

Harsono, 2001. Exercise Physical Conditions. Bandung: Library List

Hariadi, 2017. Development of Authentic Instrument for Assessing Social Attitude Aspects in Physical Education, Sports and Health. J ournal of Sports Science, Vol.16

Lutan Rusli, et al.2000. The basics of coaching. J akarta: Ministry of National Education

Mustari, Mohammad. 2011. Value of Reflection Character for Character Education. Yogyakarta: Laksibang Pressindo

Moleong, L. J . 2006. Qualitative Research Methodology. Revised Edition. Bandung: PT Remaja Rosdakarya

Sriundy, 2015. Research Methodology. Surabaya: Unesa University Press

Sriundy, 2009. Teaching Evaluation. Surabaya: ISORI East J ava

Weiyun Chen, 2015. Manipulative skills in competency and health-related physical fitness in elementary school students. USA 